\title{
Climatic Trends at Namulonge in Uganda: 1947-2009
}

\author{
F. N. W. Nsubuga \\ Department of Geography, Geoinformatics and Meteorology \\ Faculty of Natural and Agricultural Sciences, University of Pretoria \\ Pretoria, 0002, South Africa \\ E-mail: nwasswa@gmail.com \\ J. M. Olwoch \\ Department of Geography, Geoinformatics and Meteorology \\ Faculty of Natural and Agricultural Sciences, University of Pretoria \\ Pretoria, 0002, South Africa \\ E-mail: jane.olwoch@up.ac.za \\ C. J. de W. Rautenbach \\ Department of Geography, Geoinformatics and Meteorology \\ Faculty of Natural and Agricultural Sciences, University of Pretoria \\ Pretoria, 0002, South Africa \\ E-mail: hannes.rautenbach@up.ac.za
}

Received: December 23, 2010 Accepted: January 13, 2011 doi:10.5539/jgg.v3n1p119

\begin{abstract}
This paper investigates rainfall and temperature trends at Namulonge parish, in Wakiso district of Uganda using statistical techniques. Daily-observed temperature and rainfall records were aggregated into monthly means over a period of more than 55 years. These records were analyzed in an effort to identify both seasonal trends and shifts in climate. This was achieved by using non- parametric (Mann-Kendall) and parametric (linear regression) techniques. The analysis shows that total rainfall during the March-May season decreased, while maximum temperatures were increasing during the months between April and September, with both trends statistically significant at $5 \%$ confidence level. The Mann-Kendall test revealed that the number of wet days reduced significantly. Temperatures were found to be warmer and rainfall higher in the first climate normal compared to the recent 30 years. Results revealed that April was the only month with a statistically significant rainfall trend.
\end{abstract}

Keywords: East Africa, Uganda, Climatic trends, Namulonge, Statistical trends analysis

\section{Introduction}

It is known that temperature and rainfall are regarded as climate parameters with large spatial and temporal variations (Ogallo, 1993) and are useful to consider in climate change studies (Kafle and Bruins, 2009). That is why a great deal of work has been done over the last three decades in detecting changes in monthly total rainfall and mean temperatures in various parts of the world (Aguilar et al., 2005 and references there in). New et al (2005) also indicates studies documenting such changes at a global, regional and national scale. Regional studies concerning some analysis of maximum and minimum temperature trends have been outlined by (Del Rio et al., 2007). In Africa King'uyu et al., 2000; Hulme et al., 2001; Kruger and Shongwe, 2004 and references there in; Mahe et al., 2001; Mahli and Wright, 2004; Schreck and Semazzi, 2004; Domroes and El-Tantawi, 2005, amongst others, have conducted national and regional studies of recent trends and variability in monthly climate. However, there has been little work done on rainfall and temperature related trend studies in Uganda, primarily because of a difficulty in obtaining data. With climate variability and change a reality (Kruger and Shongwe, 2004) it is important to be updated and informed on observed climatic trends from this part of the world, where 
livelihoods are greatly dependent on climate. Such results may assist in planning for agriculture, food security, livelihoods and water supply and can also be of great value to mitigate possible impacts on society, the economy and the environment. Important to note is that rainfall and temperature have a direct influence on plant growth and livelihoods (IPCC, 2007).

Ogallo $(1984,1988,1993)$ gave detailed descriptions of the climate systems that modulate the space and time characteristics of rainfall and temperatures over East Africa, including Uganda. At the equator temperatures are predominantly determined by the degree of outgoing long-wave radiation, or heat emission from the Earth's surface. The most important systems responsible for Uganda's rainfall include; (1) the Inter-Tropical Convergence Zone (ITCZ), (2) subtropical anticyclones, (3) monsoonal winds and (4) the moist westerly winds from Congo basin. Local influences such as large water masses, human activities and topography also play a role (Basalirwa, 1995; Nicholson, 1996; Beltrando, 1990). A combination of these factors and especially the bi-annual propagation of the ITCZ across the region results in four broad rainfall seasonal patterns over most parts of East Africa and Uganda as recognized by the East African Meteorological Department in 1963 (Basalirwa, 1995). For example, December to February is generally dry, when the ITCZ is located to the south. Any rain during this time is locally driven (e.g. by the Lake Victoria's lake/land breeze effect). March to May is commonly known as the "long rains" season, which is modulated by synoptic scale circulation associated with the ITCZ and the Mascarene anticyclone (Basalirwa, 1995; Nicholson, 1996). The Mascarene anticyclone is a high pressure cell over the Indian Ocean, which is also the driving force behind the southeast monsoon, whose full force is usually felt during July and August. June to August is a general dry season except for parts in northern Uganda where rains are associated with the influx of moist westerly Congo air mass modulated by the Atlantic anticyclone.

The September to November season, also known as the"short rains" season is the second rainy season and is also associated with meridional ITCZ propagation. Because of these systems most of Uganda has a mean annual rainfall, of approximately $1200 \mathrm{~mm}$ (Nicholson, 1996). Previous studies provide some evidence that a bimodal rainfall regime dominates in the south of Uganda, while a unimodal distribution is more apparent above $3^{0}$ North (Komutunga and Musiitwa, 2001).

The main objectives of this present study is to identify possible statistically significant trends in both temperature (maximum and minimum) and rainfall over the Namulonge area in Uganda during recent decades when the global warmiing signal is intensified.

\section{Data and methodology}

\subsection{Study site description and general climatology}

According to the "Busukuma sub-county council, Three year development plan, 2009-2012", Namulonge is one of the villages in Busukuma parish, Kyaddondo County in the Wakiso district of Uganda. Namulonge is an area located just a few kilometers away from the equator in Uganda, on latitude $0^{0} 5^{\prime}$ North and longitude $32^{0} 61^{\prime}$ 'East. The area lies at an altitude between $900-1340 \mathrm{~m}$ above mean sea level. Topography is undulating, characterized with flat-topped hills, dissected by broad valleys that are occupied with swamps. This location exposes Namulonge to an equatorial climate characterized by comprehensive sunshine associated with high temperatures and high rainfall. Mean total rainfall received throughout the year is in the order of $1170 \mathrm{~mm}$, and it is bimodal in nature with two wet seasons(March to May and September to November), while the dry months are January to February and July to August. Maximums in temperature are experienced in February, while minimums occur in July. Namulonge village has 424 households and total populations of 1743 people from which 835 are female and 908 are male ( according to a 2009 estimate).

Namulonge is well known for intensive smallholder agricultural practices and is also a research site of the National Crop Resources Research Institute (NaCRI), which strives to develop varieties and farming technology for the people of Uganda. It is rural in nature and most of the residents are either current or past employees of the research institute. Agricultural practices in and around Namulonge are therefore significantly influenced by $\mathrm{NaCRI}$. Maximum and minimum temperatures as well as rainfall have been recorded at the NaCRI since the late 1940s.

In view of the dependence of the area's population on climate for its economy, the following question is frequently asked: "Is Namulonge in the process of drying out and cooling down or vice versa?" Such a question is bound to arise simply because some recent literature suggests that equatorial African countries might warm up to $1.4^{\circ} \mathrm{C}$ above the current temperature by the 2050s (Hulme et al., 2001). Some natives (through personal communication) believe that, in recent years, rainfall has become and that temperatures are warmer than 30 to 40 years ago. Samson (1952), however, points out that one cannot rely on human memory alone, and that it is more 
desirable to find answers through science, especially with scientists continuously informing society that future weather might become increasingly unpredictable and extreme (Cheema et al, 2006). It is therefore important that the climatology of Namulonge is scientifically analyzed and understood, with the objective of identifying changes in historical climate data at an early stage. This might lead to an early identification of changes in climate, which can again contribute to the mitigation of the impacts of such changes on society.

\subsection{Temperature and rainfall data}

Meteorological data for Namulonge has been recorded on a daily basis at the (NaCRI). It is then kept on record at the Department of Meteorology in Kampala, where it is entered and archived using climate-computing format. Data are then quality checked using visual inspections of temperature and rainfall plots. For this study monthly means of rainfall as well as minimum and maximum temperatures were loaded into the Microsoft Excel data manipulation system and A n Clim (v5.108) soft ware (Stepanek, 2007) for analysis and graphical output. A number of time series were derived, namely: average monthly maximum temperature (Tmax), average monthly minimum temperature (Tmin), and average monthly total rainfall. Analysis was carried out for time periods of all years 1947-2009 for rain, but only for the period 1953 to 2008 for temperature.

\subsubsection{Seasonal trends}

In order to further understand the intra- seasonal change, rainfall and temperature records were analyzed for the four seasons; December-January-February (DJF); March-April-May (MAM); June-July-August (JJA); September-October-November (SON). Nicholson, (1986) also found these four seasons to be appropriate for equatorial Africa.

\subsubsection{Trends in climate normals}

In order to quantify whether trends appear during a particular time interval of the reference period, time series are further divided into the following two partially overlapping 30 year periods: temperature (1953 to 1982 and 1979 to 2008), rainfall (1947 to 1977 and 1978 to 2009). Such climatic periods also referred to as climate normals, have been used in the work of (Longobardi and Villani, 2009; Cheema et al., 2006; Piccareta et al., 2004; and Ogallo, 1981). The second climatic normal from about 1979 is regarded as very important to the scientific community since it represents the most recent years or climate normal in climate change studies and the period lies with theWorld Meteorogical Organisation (WMO) recommended baseline period for climate studies. This is the period in which a number of studies on Uganda (Kizza et al., 2009; Mubiru et al., 2009; Basalirwa, 1995) amongst others have been conducted in order to understand climate variability and change in the region. For example, Kizza et al. (2009), investigated the temporal distribution of rainfall in the lake Victoria basin on seasonal to annual time scales, using an updated dataset with records covering a period between 1903 and 2006 to test for statistical significant trends in rainfall data. Their results showed that positive trends mostly dominated at stations located north of the basin. They also found that, the 1960s experienced pronounced rainfall in the basin, and at the same time seasonal rainfall analysis showed that the short rains tend to have more trends than the long rains. On the other hand Mubiru et al.,(2009) used a historical data set of daily rainfall and temperature from 37 representative stations across ten agricultural production zones of Uganda, to generate characteristics of seasons based on monthly time scales, and changes in land cover. The influence of climate, farmer's perceptions concerning climate change with coping strategies used in response to climate change were also investigated. They were able to identify that monthly total rainfall and rain days were decreasing, but could not find any evidence in the data that rainfall was increasing or decreasing on the annual time scale. They also found that maximum temperatures were increasing, although the minimums of the daily maximums changed faster than the minimums. None of these studies however, has been able to carry out an in-depth study on trends at a single station in an area as important as Namulonge.

\subsubsection{Trend analysis}

With the aim to identify trends and applying cross verification, both parametric (linear regression analysis) and nonparametric (Mann-Kendall tests) statistical procedures are applied on historical data. Temperature (maximum and minimum) and rainfall trends for each month are then calculated. Also, data has been analyzed for trends for the four seasons in order to understand the intra-seasonal change. The procedures involved in Mann-Kendall statistic have been explained in literature ( see for example: Piccareta et al, 2004, CRCCH, 2005; Modarres and da Silva, 2007; Kampata et al., 2008; Caloieroe et al., 2009; Kizza et al., 2009; and Longobardi and Villani, 2009). In more detail the Mann-Kendall(Mk) test is applied by considering the statistic S as: 


$$
S=\sum_{k=1}^{n-1} \sum_{j=k+1}^{n} \operatorname{sgn}\left(x_{j}-x_{k}\right)
$$

Where $\mathrm{x}_{i}$ is the data value at time $i, n$ is the length of the data set and $\operatorname{sgn}(z)$ is equal to $+1,0,-1$,if $z$ is greater than, equal to, or less than zero respectively. The null hypothesis is that $\left(\mathrm{H}_{\mathrm{o}}=\right.$ no trend) for a given level of significance. The mean $\mathrm{E}(\mathrm{S})$ and variance $\mathrm{V}(\mathrm{S})$ of the statistic $\mathrm{S}$ are obtained by:

$$
\mathrm{E}(\mathrm{s})=0,
$$

$$
\operatorname{VAR}(S)=\frac{1}{18}\left[n(n-1)(2 n+5)-\sum_{p=1}^{q} t_{p}\left(t_{p}-1\right)\left(2 t_{p}+5\right)\right]
$$

Here $q$ is the number of tied groups (sample data with the same value) and $t_{p}$ is the number of data values in the $\mathrm{p}^{\text {th }}$ group. The values of S and VAR (S) are used to calculate the test statistic $\mathrm{Z}$ as follows:

$$
Z= \begin{cases}\frac{S-1}{\sqrt{\operatorname{VAR}(S)}} & \text { if } S>0 \\ 0 & \text { if } S=0 \\ \frac{S+1}{\sqrt{\operatorname{VAR}(S)}} & \text { if } S<0\end{cases}
$$

The presence of a statistically significant trend is evaluated using the $\mathrm{Z}$ value. A positive (negative) value of $\mathrm{Z}$ indicates an upward (downward) trend. To test for either an upward or downward monotone trend at $p$ significance, $H_{o}$ is rejected if the absolute value of $Z$ is greater than $Z_{1-p / 2}$, obtained from the standard normal cumulative distribution table. In this paper significance levels of $p=0.05$ were applied.

A linear regression test was also used to test for trend in this study. This is a parametric test that assumes that the data are normally distributed. It tests whether there is a linear trend by examining the relationship between time (x) and the variable of interest (y). The regression gradient is obtained by:

$$
b=\frac{\sum_{i=1}^{n}\left(x_{i}-\bar{x}\right)\left(y_{i}-\bar{y}\right)}{\sum_{i=1}^{n}\left(x_{i}-\bar{x}\right)^{2}}
$$

And the intercept is obtained by:

$$
a=\bar{y}-b \bar{x}
$$

The test statistic $\mathrm{S}$ is:

$$
\begin{aligned}
\mathrm{S} & =\mathrm{b} / \sigma \\
\text { Where } \sigma & =\sqrt{\frac{12 \sum_{i=1}^{n}\left(y_{i}-a-b x_{i}\right)}{n(n-2)\left(n^{2}-1\right)}}
\end{aligned}
$$

The test statistic $\mathrm{S}$ follows a student-t distribution with $\mathrm{n}-2$ degrees of freedom under the null hypothesis (critical test statistics values for various significance levels can be obtained from Student's $t$-statistic tables). Equations shown above were sourced from the trend user guide at (www.toolkit.net.au/trend-CRCCH, 2005).

\section{Results and discussion}

Climatic trends of rainfall as well as, maximum, minimum and average temperature of each month are discussed below. Monthly average temperature and rainfall of the studied station with their linear trend values and statistical significance are shown in Table 1. Data was tested for normality using a normal probability plot (Chambers, 1983) also see http://www.itl.nist.gov/div898/handbook/eda/section3/

normprpl.htm, which is a graphical technique for assessing whether or not a data set is approximately normally distributed. The data are plotted against a theoretical normal distribution in such a way that the points form an approximated straight line. Departures from this line indicate departures from normality. The result which 
justifies normality is indicated in the normal probability plot in (Figure 1). The points on this plot depict an acceptable linear pattern, which indicates that the normal distribution is a good model for the data set with $\mathrm{p}=$ 0.000 .

\subsection{Temperature trends}

Figure 2(a) and 2(b) depict the minimum and maximum temperature anomalies of Namulonge during the period 1953 to 2008. The figure also reveals that mean monthly maximum temperatures have been increasing after the 1970's (figure 2a). On the other hand Figure (2b) illustrates that mean monthly minimums are decreasing, which is indicative of a warming in minimum temperatures since the 70 's. The station showed little annual variations during the study period.

\subsubsection{Maximum temperature trends}

The analysis revealed increasing trends in maximum temperatures for each month from January to December (Table 1). These increasing trends are statistically significant for the months of April to September and December. While October to November and January to March, are associated with statistically insignificant positive trends at the 5\% confidence level. This finding is not far from what Hulme et al. (2001), had observed in the warming trends in Africa, where warming in JJA and SON was larger than that of DJF and MAM. February recorded the highest average maximum temperature of $29.5^{\circ} \mathrm{C}$ followed by March with $29.1^{\circ} \mathrm{C}$ (Table 1) during the period of analysis.

High peaks of temperatures were experienced in 1992 and 1993, while 1990 recorded cooler maximum temperature (Figure 2a). The lowest average maximum temperature recorded was in July $\left(26.9^{0} \mathrm{C}\right)$. A closer look at the average maximum temperatures show that the second climate normal has been warmer compared to the first climate normal (Table 1). This finding is in line with IPCC, (2001a) findings, where 1990s were identified as the warmest decade (Domroes and El-Tantawi, 2005). The positive trend in maximum temperatures are significant in all four seasons, but out side the $5 \%$ confidence level (Table 2).

These findings compares well with what New et al., (2006) found out in their study of daily temperatures and precipitation from fourteen south and west african countries over the period 1961 to 2000, which excluded the Namulonge station, where they came to a conclusion that temperatures were warming in most of the regions analyzed. This also indicates that day time temperatures were increasing.

\subsubsection{Minimum temperature trends}

The analysis reveals that minimum temperature trends in the months of November to February and June to September were positive while those in March to May and October were negative. The trends for most of the months were non significant at a 5\% confidence level, with the exception of April and July where trends were significant at a low confidence level. The lowest average minimum temperature were experienced during January and July, and the highest of the minimums were recorded during April and May (Table 1). Higher peaks of the minimums are evident in 1968 and 1970, while the lowest of minimums were recorded in 1989/90/91 (Figure $2 b$ ) from where they have started to increase. According to Oxfam (2008), minimum temperatures have been rising faster than maximum temperatures in Uganda. The report reveals that minimum temperatures rose from about 1960 to 1982, then declined, and rose again since the 1990s. These findings are not far from the findings of this paper.

Trends in minimum temperature are significantly negative in the MAM season at a rate of -0.25 per decade, while the other three seasons are experiencing positive trends (Table 2). The increasing trends are only significant in the JJA season and insignificant for DJF and SON seasons. These notable changes have a low level of confidence except for the SON season, which lies in the 5\% confidence level. The trends in minimum temperatures over the whole study period, however, shows an increasing trend of 0.001 which is insignificant $(\mathrm{t}$ $=-0.020<0.05)$.

Minimum temperatures were high, with a mean of $15.9^{\circ} \mathrm{C}$ in the first climate normal, and have shown a slight decrease in the second climate normal with a mean of $15.7^{\circ} \mathrm{C}$. January and july have experienced the lowest minima in both climate normals (Table 1). When comparing the mean annual maximum and the minimum temperatures, the Mann-Kendall test $(Z)$ for trend indicates a statistically significant increasing trend at 0.01 for the former $(Z=4.09)$, where as the later $(Z=0.26)$ shows no statistically significant trend at 0.10 .

\subsection{Rainfall trends}

Rainfall trend is decreasing for most months except for January, September and December, though this negative trend is not statistically significant, at a $5 \%$ confidence level. 
The analysis further reveals that on average, the maximum rainfall received in the last sixty-three years, was recorded in April with a mean monthly total of $153.8 \mathrm{~mm}$, followed by November with $139.2 \mathrm{~mm}$ (Table.1). Indeje et al. (2000), point out that, as much as most parts of East Africa are experiencing dry conditions, the Lake Victoria basin, central and western Uganda are among the few areas that receive significantly high rainfall during the month of April. Average rainfall for the $1^{\text {st }}$ climate normal (1947-1977) is greater than the $2^{\text {nd }}$ climate normal (1978 to 2009) for most of the months, except for May, September and October (Table 1). The rainfall trend per decade shows the same characteristics.

The increase in rainfall during the months of September, December and January was experienced in the second normal (1978 to 2009). The average rainfall of April is $156.7 \mathrm{~mm}$ per year, which is highest among all months and in both normals (Table 1). The first climate normal (1947 to 1977) recorded a mean annual rainfall of 1269 $\mathrm{mm}$, with the highest amount of total rain being $1635 \mathrm{~mm}$ in 1951, while the lowest total in annual rainfall received for the first climate normal is $964 \mathrm{~mm}$ in 1952. Namulonge recorded a lower mean annual total rainfall $(1147 \mathrm{~mm})$, lowest maximum $(1475 \mathrm{~mm})$ and low minimum total rainfall $(676 \mathrm{~mm})$ in the second climate normal compared to the first climate normal. This is in line with findings by New et al. (2006) that indicated a decrease in the regions' averaged total rainfall although not statistically significant. Comparison of the two normals of rainfall is clearer from Figure 3.

The month of May receives on average the highest rainfall of $34.7 \mathrm{~mm}$ (Table 1). The average total amount of rainfall received in Namulonge for the period 1947 to 2009 was approximately $1198 \mathrm{~mm}$, which is very close to values in Basalirwa (1995) and Nicholson (1996) for east Africa. The years during which, total amounts of rainfall of below $1000 \mathrm{~mm}$ were recorded, are 1949, 1952, 1983, 1985, 1986, 1987, 1989, 1991, 1995 and 2005 (Figure 4).

The year during which, the lowest total of $675.6 \mathrm{~mm}$ was recorded, nearly half the average of rainfall received in east Africa was 1989. Years from the analysis during which total rain of above $1500 \mathrm{~mm}$ were recorded include 1951, 1961, 1962, 1963, 1964, 1968, 1997 (Figure 4). Four of these years (1951, 1961, 1963, and 1997) are also indicated in Kizza et al (2009), as years that received anomalous rain. Nicholson (1996) on the other hand pointed out that 1951, 1963, 1968, were years of high peaks that corresponded to Pacific El Niño/Southern Oscillation (ENSO). The plot of Namulonge shows that, 1961 and 1997/98 were years of high rainfall. These rainfall peaks compare very well with flood/El Niño events in East Africa as characterized by (Schreck and Semazzi, 2004). The analysis also shows that the1960s were the wettest years at this station, which confirms earlier findings that during this time many east African lakes rose by over $2 \mathrm{~m}$ because of the high rain that was received (Ogallo, 1993; Nicholson, 1996; Nicholson and Yin, 2001).

The DJF and SON seasons have experienced a positive rainfall trend ( 0.047 and 0.254 respectively), while MAM and JJA show a decreasing rainfall trend. The trend is only significant for MAM (-6.63), while the rest of the seasons the trend was non significant at a $5 \%$ confidence level (Table 2).

The MAM season contributes a larger parcentage (38.3\%) to the annual total rainfall amounts received in Namulonge. This result collaborates with what previous East Africa studies found (Ogallo, 1993; Nicholson, 1996; Indeje et al., 2000). They were of the opinion that the high rainfall is modulated by local factors rather than large-scale factors during the MAM season. On average MAM and SON rainfall totals account for $72 \%$ of the mean rainfall in Namulonge. Mean annual total rainfall of the seasons DJF, MAM, JJA, SON are $100.2 \mathrm{~mm}$, $68.0 \mathrm{~mm}, 140 \mathrm{~mm}, 72 \mathrm{~mm}, 122 \mathrm{~mm}$ respectively. A closer analysis shows that the annual trend in rainfall is negative. This may have severe impacts on soil moisture and agricultural production in Namulonge, given the fact that the cropping system and planting time highly depends on rainfall distribution (Phillips and Mcintyre, 2000). The decrease is, however, not statistically significant at a $5 \%$ confidence level, with a decadal trend of -0.841 during the period 1947-2009 (Table 2). Namulonge does not fall in the 67\% of cases which had significant positive trends as established by (Kizza et al., 2009).

The Mann- Kendall test was applied to detect trends in the annual number of wet days (number of days with precipitation higher than $1 \mathrm{~mm}$ ). A negative trend of -2.36 per year was observed at Namulonge station. This trend is statistically significant at $p<0.05$. The annual distribution of wet days during the period of study are shown in Figure 5, which also reveals that there were more wet days in the earlier years of the series than in the latter period after 1990.

\subsection{Trends in interannual and intra-annual rainfall}

To study rainfall trends in the Kwazulu-Natal Drakensburg region of South Africa, Nel (2009) considered data at each station over the period 1955-2000 as an arithmetic mean for the region. To test for trends in annual rainfall at Namulonge, data for the period 1947-2009 were considered to calculate the arithmetic mean for the station, 
and this mean for each year was plotted. Mean annual rainfall figures for Namulonge ranges from $49 \mathrm{~mm}$ to 149 $\mathrm{mm}$ (Figure 6). A negative linear trend (-0.18) in mean annual rainfall was detected which is not statistically significant at $5 \%$.

Rainfall in Namulonge is seasonal, and seasonality can be described through the monthly rainfall totals as a percentage of the total annual rainfall (Nel and Sumner, 2006; Nel, 2009). The intra-annual rainfall depicts a positive trend for the period 1947 to 2009 (Figure 7). Knowledge of interannual and intra-annual rainfall distribution of rainfall can be of great importance when looking at ways to solve regional water resources problems (Schulze, 1979 in Nel and Sumner, 2006).

\section{Conclusions and recommendations}

This paper presents the first attempt to analyze climate trends at Namulonge over the past half century. The analysis was based on data obtained from the Department of Meteorology in Kampala-Uganda. The choice of the statistical approach used is in line with those used frequently by other research when explaining climatic trends elsewhere in the world.

Results show monthly maximum temperatures for the period under consideration have been increasing significantly (Table 2). The second climate normal has been warmer than the first climate normal of the period under study at Namulonge. IPCC (2001), indicated that global average surface temperatures were increasing since 1976, at a rate of $0.15^{\circ} \mathrm{C}$ per decade. This study has revealed that maximum temperatures at Namulonge have increased significantly at a rate of $0.17^{\circ} \mathrm{C}$ per decade (Table 2). Records indicate that 2005 was the hottest of all years with a mean monthly average temperature of $32.8^{\circ} \mathrm{C}$. It also became evident that variation of mean monthly temperatures throughtout the year is very small ranging between $1^{0} \mathrm{C}$ to $2^{0} \mathrm{C}$.

It is also shown from the 56 year record that mean annual minimum temperature was increasing but with a statistically insignificant trend. However minimums in the minimum temperatures reflect a stastistically significant trend which is increasing. This implies that, the nights were warming, especially from the 1990's (Figure $2 b$ ), which might be an indication of global climate change. Warming temperatures are likely to impact on the livelihoods of the people, their health and water resources among others. For example vectors, pathogens and hosts that cause disease survive and reproduce within certain optimal climate conditions. Changes in these conditions might therefore significantly modify properties of disease transmission (Nema, 2007). Increased precipitation may increase the presence of disease vectors by expanding the size of existent larval habitat and creating new breading grounds. Further more increases in local temperatures may have detrimental effects on sensitive development stages of plants such as flowering, and thereby might reduce grain yield and quality.

Riebsame et al. (1995) argues that elevated temperatures may enhance evaporation losses, unless they are compensated by increased precipitation. Even runoff is likely to be further reduced (IPCC, 2007). Muchena and Iglesias, (1995), in Abraha and Savage (2006) through model simulations have concluded that temperature increase of $2^{0} \mathrm{C}$ or $4^{0} \mathrm{C}$ reduced maize yields which show that crop production is significantly affected by climatic variables. Given this argument, the increasing temperatures may impact water resources in and around Namulonge and also alter crop water balances.

Rainfall is decreasing especially in the MAM season. MAM and SON are wet seasons with average rainfall ranging between $110 \mathrm{~mm}$ and $155 \mathrm{~mm}$. These seasons are seperated by two seasons of lower rainfall. Over the first 30 years higher rainfall was recorded compared to the recent 30 years. Analysis shows that the early 1960s were the wettest years on record.

The results from this study can be ably interpreted in the context of other impacts, which Orindi and Eriksen (2005 in Nema,2007) have noted,meaning that it is likely that constraints on livelihood could be exacerbated.

The majority of Ugandan farmers, like those in Namulonge, practice rain-fed agriculture which is sensitive to flactuations in weather and climate conditions. Declining rainfall may lead to crop failure, increasing temperatures and reduced rainfall can even lead to scarcity of water resources for human consumption and watering of livestock. Increases in temperatures may lead to a decline in milk and meat production, largely because the animals remain in shade instead of foraging. Crop water balances may be affected through changes in precipitation and other climatological elements such as the increase in evapotranspiration (IPCC, 2007). The impacts of land degradation at Namulonge and the surrounding areas are already quite severe. The population growth, human settlements, transport, agriculture, utilization of trees for energy and other human activities are probably responsible for most anthropogenic forcings.

The climate systems in Namulonge are still complex and not fully understood. Some studies, for example like that of King'uyu et al (2000), have come up with results that points towards a significant rise in night temperatures at several locations. Climate model simulations also anticipate increases in rainfall with in 
Namulong region where as this study shows that rainfall is on the decrease at the station. Further research into the underlying local factors that influence climate is therefore required. Future studies ought to investigate aspects of urbanisation among other factors on temperatures. A study on the possible impacts of global warming and climate change on food crops like maize, beans, potatoes, bananas and commercial activities like poultry, fish farming and flower farming is also required.

\section{Acknowledgements}

Many thanks to the Uganda Department of Meteorology for availing the data required for this study. The authors are also grateful to the anonymous reviewers for the precious remarks and comments, which led to improving the initial version of this paper.

\section{References}

Abraha, M. G. \& Savage, M. J. (2006). Potential impacts of climate change on the grain yield of maize for the midlands of KwaZulu-Natal, South Africa. Agriculture, Ecosystems and Environment, 115, 150-160. doi:10.1016/j.agee.2005.12.020, http://dx.doi.org/10.1016/j.agee.2005.12.020

Aguilar, E., Peterson, T. C., Ramirez Obando P., Frutos R., Retana, J. A., Solera, M., Soley, J., Gonzalez Garcia I., Araujo, R. M., Rossa Santos, A., Valle, V. E., Brunet, M., Aguilar, L., Alvarez, L., Bautista, M., Castanon, C., Herrera, L., Ruano, E., Sinay, J. J., Sanchez, E., Harnandez Oviedo, G. I., Obed, F., Salgado, J. E., Vazquez, J. L., Baca, M., Gutierrez, M., Centella, C., Espinosa, J., Martinez, D., Olmendo, B., Ojeda, Espinoza, C. E., Nunez, R., Haylock, M., Benavides, \& Mayorga, R. (2005). Changes in precipitation and temperature extremes in Central America and northern South America, 1961-2003. Journal of geophysical research, 110, D23107, doi:10.1029/2005JD006119. doi:10.1029/2005JD006119, http://dx.doi.org/10.1029/2005JD006119

Basalirwa, C. P. K. (1995). Delineation of Uganda into climatological rainfall zones using the method of principal component analysis. International Journal of Climatology, 15, 1161-1177. doi:10.1002/joc.3370151008, http://dx.doi.org/10.1002/joc.3370151008

Caloiero, T., Coscarelli, R., Ferrari, E., Mancini, M. (2009). Trend detection of annual and seasonal rainfall in Calabria (Southern Italy). International Journal of Climatology, 31, 44-56. doi:10.1002/joc.2055, http://dx.doi.org/10.1002/joc.2055

Cheema, M. A., Farooq, M., Ahmad, R., Munir, H. (2006). Climatic trends in Faisalabad (Pakistan) over the last 60 years (1945-2004). Journal of Agriculture and Social Sciences, 2(1), 42-45.

CRCCH., (2005). Co-operative Research Centre for Catchment Hydrology. TREND User Guide, p 17.

Domroes, M. \& El-Tantawi. (2005). Recent temporal and spatial temperature changes in Egypt. International journal of Climatology, 25, 51- 63. doi:10.1002/joc.1114, http://dx.doi.org/10.1002/joc.1114

Hulme, M., Doherty, R., Ngara, T., New, M., \& Lister, D. (2001). African climate change: 1900-2100. Climate Research, 17, 145-168. doi:10.3354/cr017145, http://dx.doi.org/10.3354/cr017145

Indeje, M., Semazzi, F. H. M., Ogallo L. J. (2000). Enso signals in East African Rainfall seasons. International journal of Climatology, 20, 19-46. doi:10.1002/(SICI)1097-0088(200001)20:1<19::AID-JOC449>3.0.CO;2-0, http://dx.doi.org/10.1002/(SICI)1097-0088(200001)20:1<19::AID-JOC449>3.0.CO;2-0

IPCC. (2001). Climate Change 2001: The Scientific Basis. Contribution of Working Group I to the Third Assessment Report of the Intergovernmental Panel on Climate Change [Houghton, J. T., Y. Ding, D. J. Griggs, M. Noguer, P. J. van der Linden, X. Dai, K. Maskell, and C. A. Johnson (eds.)]. Cambridge University Press, Cambridge, United Kingdom and New York, NY, USA, 881

IPCC. (2007). Climate Change 2007: The Physical Science Basis. Contribution of Averyt, K. B., Tignor, M. \& Miller, H. L., Eds., Cambridge University Press, Cambridge, 996 .

Kampata, J. M., Parida, B. P., Moalafhi, D. B. (2008). Trend analysis of rainfall in the headstreams of the Zambezi River Basin in Zambia. Physics and Chemistry of the Earth, 33, 621-625.

Kafle, H. K. \& Bruins, H. J. (2009). Climatic trends in Israel 1970-2002: warmer and increasing aridity inland. Climatic Change, 96, 63-77. doi:10.1007/s10584-009-9578-2, http://dx.doi.org/10.1007/s10584-009-9578-2

Kruger, A. C. \& Shongwe, S. (2004). Temperature trends in South Africa: 1960-2003. International journal of Climatology, 24, 1929-1945. doi:10.1002/joc.1096, http://dx.doi.org/10.1002/joc.1096

King'uyu, S. M., Ogallo, L. A., Anyamba, E. K. (2000). Recent Trends of Minimum and Maximum surface temperature over Eastern Africa. Journal of Climate, 13, 2876-2886. 
doi:10.1175/1520-0442(2000)013<2876:RTOMAM>2.0.CO;2, http://dx.doi.org/10.1175/1520-0442(2000)013<2876:RTOMAM>2.0.CO;2

Kizza, M., Rhode, A., Xu, Y. C., Ntale, H. K. \& Halldin, S. (2009). Temporal rainfall variability in the Lake Victoria Basin in East Africa during the twentieth century. Theoretical Applied Climatology, 98, 119-135. doi:10.1007/s00704-008-0093-6, http://dx.doi.org/10.1007/s00704-008-0093-6

Longobardi, A. \& Villani, P. (2009). Trend analysis of annual and seasonal rainfall time series in the Mediterranean area. International journal of Climatology.

New, M., Hewitson, B., Stephenson, D. B., Tsiga, A., Kruger, A., Manhique, A., Gomez, B., Coelho, C. A. S., Masisi, D. N., Kululanga, E., Mbambalala, E., Adesina, F., Saleh, H., Kanyanga, J., Adosi, J., Bulane, L., Lubega, F., Mdoka, M. L., \& Lajoie, R. (2006). Evidence of trends in daily climate extremes over southern and West Africa. Journal of Geophysical Research, 111.

Mahli, Y. \& Wright, J. (2004). Spatial patterns and recent trends in the climate of tropical rainforest regions. Phil.trans.R.Soc.Lond., 359, 311-329. doi:10.1098/rstb.2003.1433, http://dx.doi.org/10.1098/rstb.2003.1433

Modarres Reza \& Vicente de Paulo Rodrigues da Silva. (2007). Rainfall trends in arid and semi arid regions of Iran. Journal of the Arid Environments, 70, 344-355. doi:10.1016/j.jaridenv.2006.12.024, http://dx.doi.org/10.1016/j.jaridenv.2006.12.024

Mubiru, N. D., Agona, A., Komutunga, E. (2009). Micro-level analysis of seasonal trends, farmers' perception of climate change and adaptation strategies in eastern Uganda. Seasonality revisited. Paper presented at International conference, institute of development studies, UK, 8-10 July, 2009.

National Environmental management authority, (2006/07) State of environment report for Uganda, NEMA Kampala. Pp 332.

Nicholson, S. E. \& Yin, X. (2001). Rainfall conditions in equatorial east Africa during the nineteenth century as inferred from the record of Lake Victoria. Climatic Change, 48, 387-398. doi:10.1023/A:1010736008362, http://dx.doi.org/10.1023/A:1010736008362

Nicholson, S. E. (1996). 'A Review of Climate Dynamics and Climate Variability in Eastern Africa', in Johnson, T. C. \& Odada, E. eds. The Limnology, Climatology and Paleo-climatology of the East African Lakes, Gordon and Breach, Amsterdam, 25-56.

Nel, W. \& Sumner, P. D. (2006). Trends in rainfall total variability (1970-200) along the Kwazulu-Natal Drakensburg foothills. South African Geographical Journal, 88(2), 130-137.

Nel, W. (2009). Rainfall trends in the Kwazulu-Natal Drakensburg region of South Africa during the twentieth century. International Journal of Climatology, 29, 1634-1641. doi:10.1002/joc.1814, http://dx.doi.org/10.1002/joc.1814

Ogallo, L. (1981). Trend of rainfall in East Africa. Kenya Journal of Science and Technology, 2, 83-90.

Ogallo, L. A. (1993. Dynamics of East African Climate. Proceedings Indian Academy of Sciences. Earth and Planetary Sciences, 102(1), 203-217.

Oxfam. (2008). Turning up the heat: climate change and poverty in Uganda. Oxfam online imprint, Oxfam GB, Uganda and Oxfam GB, UK. Kampala-Uganda and Oxford-United Kingdom. [Online] Available: www.oxfam.org.uk/publication.

Phillips, J. \& Mcintyre, B. (2000). Enso and interannual rainfall variability in Uganda: implications for agricultural $\begin{array}{lllll}\text { management. International } & \text { Journal } & \text { Climatology, } & 20, & 171-182 .\end{array}$ doi:10.1002/(SICI)1097-0088(200002)20:2<171::AID-JOC471>3.0.CO;2-O

http://dx.doi.org/10.1002/(SICI)1097-0088(200002)20:2<171::AID-JOC471>3.0.CO;2-O

Piccarreta, M., Capolongo, D., Boenzi, F. (2004). Trend analysis of precipitation and drought in Basilicata from 1923 to 2000 within a southern Italy context. International Journal of Climatology, 24, 907-922. doi:10.1002/joc.1038, http://dx.doi.org/10.1002/joc.1038

Samson, H. W. (1952). The trend of rainfall in east Africa. East African Meteorological Department Serie paper.

Schreck, C. J. \& Semazzi, H. M. (2004). Variability of recent climate of Eastern Africa. International Journal of Climatology, 24, 681-701. doi:10.1002/joc.1019, http://dx.doi.org/10.1002/joc.1019

Stepanek, P. (2007). A Clim-software for time series analysis (for windows). Dept. Of Geography, Faculty of Natural Sciences, Masaryk University, Brno.1.47 MB. 
Table 1. Monthly trend values for temperature and rainfall of Namulonge. Bold values show linear trends that are statistically significant at $5 \%$

\begin{tabular}{|c|c|c|c|c|c|c|c|c|c|c|c|c|c|}
\hline & Jan & Feb & Mar & Apr & May & Jun & Jul & Aug & Sep & Oct & Nov & Dec & Period \\
\hline $\begin{array}{l}\text { Max. temperature } \\
\text { trend }{ }^{0} \mathrm{C}\end{array}$ & 0.00 & 0.02 & 0.01 & 0.01 & 0.02 & 0.03 & 0.03 & 0.02 & 0.02 & 0.01 & 0.01 & 0.02 & $1953-2008$ \\
\hline $\begin{array}{l}\text { MKRank stat. } \\
\text { (Tkrit_95\%) }\end{array}$ & -0.03 & 0.13 & 0.02 & 0.20 & 0.26 & 0.33 & 0.34 & 0.32 & 0.29 & 0.09 & 0.06 & 0.28 & \\
\hline $\begin{array}{l}\text { Max. temperature } \\
\text { trend }\left(1^{\text {st }} \text { Normal }\right)^{0} \mathrm{C}\end{array}$ & -0.02 & 0.01 & 0.00 & 0.00 & -0.02 & 0.01 & 0.00 & -0.0 & 0.03 & 0.01 & -0.03 & 0.02 & 1953-1982 \\
\hline $\begin{array}{l}\text { Max. temperature } \\
\text { trend }\left(2^{\text {nd }} \text { Normal }\right)^{0} \mathrm{C}\end{array}$ & -0.02 & -0.01 & -0.04 & 0.01 & 0.04 & 0.01 & 0.03 & 0.01 & -0.01 & 0.04 & 0.02 & 0.04 & 1979-2008 \\
\hline $\begin{array}{l}\text { Max. temperature } \\
\text { trend/ } 10 \mathrm{yrs}^{0} \mathrm{C}\end{array}$ & 0.01 & 0.17 & 0.08 & 0.15 & 0.18 & 0.26 & 0.29 & 0.23 & 0.22 & 0.10 & 0.07 & 0.23 & \\
\hline $\begin{array}{l}\text { Ave. maximum } \\
\text { temperature }^{0} \mathrm{C}\end{array}$ & 29.1 & 29.6 & 29.1 & 27.7 & 27.3 & 27.3 & 26.9 & 27.5 & 28.1 & 28.1 & 28.0 & 28.3 & $1953-2008$ \\
\hline $\begin{array}{l}\text { Ave.Max temp } \\
\left(1^{\text {st Normal })^{0} \mathrm{C}}\right.\end{array}$ & 28.9 & 29.3 & 28.8 & 27.5 & 26.9 & 26.8 & 26.3 & 27.1 & 27.8 & 28.0 & 27.8 & 28.0 & 1953-1982 \\
\hline $\begin{array}{l}\text { Ave. Max temp } \\
\left(2^{\text {nd }} \text { Normal }\right)^{0} \mathrm{C}\end{array}$ & 29.3 & 29.9 & 29.4 & 27.9 & 27.6 & 27.8 & 27.5 & 27.9 & 28.5 & 28.2 & 28.1 & 28.6 & $1963-2009$ \\
\hline $\begin{array}{l}\text { Mean monthly } \\
\text { Max. Tmax trend. }\end{array}$ & -0.01 & 0.01 & -0.01 & 0.00 & 0.02 & 0.02 & 0.02 & 0.02 & 0.02 & 0.02 & 0.00 & 0.02 & \\
\hline $\begin{array}{l}\text { MKRank stat. } \\
\text { (Tkrit 95\%) }\end{array}$ & -0.06 & 0.05 & -0.07 & 0.03 & 0.21 & 0.14 & 0.23 & 0.17 & 0.15 & 0.08 & -0.13 & 0.15 & \\
\hline $\begin{array}{l}\text { Min. temperature } \\
\text { trend }{ }^{0} \mathrm{C}\end{array}$ & 0.01 & 0.00 & -0.01 & -0.04 & -0.02 & 0.01 & 0.02 & 0.01 & 0.01 & -0.00 & 0.00 & 0.01 & $1953-2008$ \\
\hline $\begin{array}{l}\text { MK Rank stat. } \\
\text { (Tkrit 95\%) }\end{array}$ & 0.19 & 0.08 & -0.19 & -0.36 & 0.20 & 0.15 & 0.24 & 0.11 & 0.14 & -0.04 & 0.02 & 0.21 & \\
\hline $\begin{array}{l}\text { Min. temp trend } \\
\left(1^{\text {st }} \text { Normal }\right)^{0} \mathrm{C}\end{array}$ & 0.00 & 0.03 & 0.00 & 0.02 & 0.02 & 0.00 & 0.00 & 0.01 & 0.01 & 0.02 & 0.01 & -0.03 & 1953-1982 \\
\hline $\begin{array}{l}\text { Min. temp trend } \\
\left(2^{\text {nd }} \text { Normal }\right)^{0} \mathrm{C}\end{array}$ & 0.04 & 0.03 & 0.00 & -0.03 & -0.01 & 0.00 & 0.04 & 0.01 & 0.02 & 0.01 & -0.01 & 0.04 & $1979-2008$ \\
\hline $\begin{array}{l}\text { Min. temperature } \\
\text { trend } / 10 \mathrm{yrs}^{0} \mathrm{C}\end{array}$ & 0.12 & 0.02 & -0.13 & -0.38 & -0.22 & 0.08 & 0.22 & 0.08 & 0.07 & -0.03 & -0.01 & 0.10 & \\
\hline $\begin{array}{l}\text { Ave. minimum } \\
\text { temperature }{ }^{0} \mathrm{C}\end{array}$ & 15.3 & 15.5 & 16.2 & 16.4 & 16.4 & 15.8 & 15.3 & 15.5 & 15.6 & 16.0 & 16.2 & 15.4 & $1953-2008$ \\
\hline 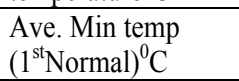 & 15.2 & 15.7 & 16.5 & 17.0 & 16.9 & 15.7 & 15.0 & 15.4 & 15.6 & 16.2 & 16.1 & 15.3 & $1953-1982$ \\
\hline $\begin{array}{l}\text { Ave. Min temp } \\
\left(2^{\text {nd }} \text { Normal }\right)^{0} \mathrm{C}\end{array}$ & 15.3 & 15.4 & 15.8 & 15.9 & 16.0 & 15.9 & 15.4 & 15.5 & 15.7 & 15.9 & 16.2 & 15.5 & $197-2008$ \\
\hline $\begin{array}{l}\text { Mean monthly } \\
\text { Min. T min trend. }\end{array}$ & 0.03 & 0.03 & -0.00 & -0.02 & -0.01 & 0.04 & 0.04 & 0.03 & 0.03 & -0.02 & 0.02 & 0.02 & \\
\hline $\begin{array}{l}\text { MKRank stat. } \\
\text { (Tkrit 95\%) }\end{array}$ & 0.22 & 0.19 & -0.01 & -0.25 & -0.02 & 0.42 & 0.31 & 0.23 & 0.29 & 0.09 & 0.23 & 0.34 & \\
\hline $\begin{array}{l}\text { Ave. Maxi-min } \\
\text { temperature }{ }^{0} \mathrm{C}\end{array}$ & 23.6 & 24.0 & 23.6 & 23.4 & 23.2 & 22.8 & 22.1 & 22.2 & 23.4 & 22.3 & 22.8 & 22.3 & $1953-2008$ \\
\hline $\begin{array}{l}\text { Rainfall trend } \\
(\mathrm{mm})\end{array}$ & 0.25 & -0.27 & -0.52 & -1.56 & -0.22 & -0.29 & -0.28 & -0.21 & 0.70 & -0.01 & -0.31 & 0.24 & $1947-2009$ \\
\hline $\begin{array}{l}\text { MK Rank stat. } \\
\text { (Tkrit_95\%) }\end{array}$ & 0.09 & -0.1 & -0.08 & -0.27 & -0.08 & -0.1 & -0.2 & -0.1 & 0.10 & 0.00 & -0.01 & 0.02 & \\
\hline $\begin{array}{l}\text { Rainfall trend } \\
\left(1^{\text {st }} \text { Normal }\right)(\mathrm{mm})\end{array}$ & 0.62 & -0.3 & -1.25 & -0.99 & -0.34 & 0.50 & 0.15 & 0.20 & 0.52 & -0.03 & 1.86 & -0.3 & 1947-1977 \\
\hline $\begin{array}{l}\text { Rainfall trend }\left(2^{\text {nd }}\right. \\
\text { Normal })(\mathrm{mm})\end{array}$ & 0.40 & 1.29 & -0.42 & 0.44 & -0.98 & -0.1 & 1.26 & -0.1 & 2.61 & 0.60 & 0.20 & 1.26 & $1978-2009$ \\
\hline $\begin{array}{l}\text { Rainfall trend/ } 10 \\
\text { yrs (mm) }\end{array}$ & 2.46 & -2.7 & -5.22 & -15.6 & -2.18 & -2.9 & -2.8 & -2.1 & 7.04 & -0.08 & -3.06 & 2.38 & \\
\hline $\begin{array}{l}\text { Average rainfall } \\
(\mathrm{mm})\end{array}$ & 54.9 & 61.0 & 114.3 & 153.8 & 128.9 & 66.6 & 60.7 & 82.1 & 114.9 & 125.9 & 139.2 & 87.1 & $1947-2009$ \\
\hline $\begin{array}{l}\text { Ave. Highest } \\
\text { rainfall }(\mathrm{mm})\end{array}$ & 21.3 & 22.8 & 33.0 & 32.8 & 34.8 & 24.8 & 21.4 & 25.0 & 31.9 & 30.4 & 33.1 & 28.6 & $1947-2009$ \\
\hline $\begin{array}{l}\text { Ave. Rainfall }\left(1^{\text {st }}\right. \\
\text { Normal })(\mathrm{mm})\end{array}$ & 51.3 & 60.2 & 113.6 & 156.4 & 128.2 & 68.6 & 59.7 & 86.9 & 102.8 & 125.1 & 144.1 & 76.2 & $1947-1977$ \\
\hline $\begin{array}{l}\text { Ave. Rainfall }\left(2^{\text {nd }}\right. \\
\text { Normal })(\mathrm{mm})\end{array}$ & 54.6 & 50.8 & 113.4 & 136.5 & 129.2 & 58.8 & 57.1 & 80.8 & 122.5 & 126.0 & 120.8 & 86.8 & $1979-2008$ \\
\hline $\begin{array}{l}\text { Deviation of } \\
\text { rainfall }(\mathrm{mm})\end{array}$ & 38.3 & 42.8 & 45.3 & 64.1 & 50.9 & 34.5 & 48.0 & 43.2 & 56.5 & 48.2 & 80.1 & 56.5 & \\
\hline
\end{tabular}


Table 2. Seasonal and annual trend values of temperature and rainfall for Namulonge. Bold values show linear trends that are statistically significant at $5 \%$

\begin{tabular}{|c|c|c|c|c|c|}
\hline & DJF & MAM & JJA & SON & JAN-DEC \\
\hline Monthly total rainfall trend & 0.05 & -0.66 & -0.25 & 0.25 & -0.08 \\
\hline -Mann- Kendall stat Tkrit_95\% & 0.02 & -0.17 & -0.15 & 0.13 & 0.06 \\
\hline -Trend / decade & 0.47 & -6.63 & -2.52 & 2.54 & -0.84 \\
\hline Monthly maximum temperature trend & 0.02 & 0.01 & 0.03 & 0.01 & 0.02 \\
\hline -Mann- Kendall stat Tkrit_95\% & 0.22 & 0.23 & 0.38 & 0.22 & 0.38 \\
\hline -Trend / decade & 0.18 & 0.13 & 0.26 & 0.13 & 0.17 \\
\hline Monthly minimum temperature trend & 0.01 & -0.02 & 0.01 & 0.00 & 0.00 \\
\hline $\begin{array}{llll} & \text {-Mann- } & \text { Kendall } & \text { stat } \\
\text { Tkrit_95\% } & & & \end{array}$ & 0.21 & -0.24 & 0.27 & 0.07 & -0.02 \\
\hline -Trend / decade & 0.09 & -0.26 & 0.13 & 0.03 & 0.01 \\
\hline Monthly mean minimum $\mathrm{T}$ min & 0.03 & -0.01 & 0.03 & 0.01 & 0.02 \\
\hline $\begin{array}{llll}\text { (Tkrit_95\%) } & \text {-Mann } & \text {-Kendall } & \text { stat. }\end{array}$ & 0.29 & -0.05 & 0.41 & 0.28 & 0.29 \\
\hline -Trend / decade & 0.28 & -0.10 & 0.34 & 0.11 & 0.16 \\
\hline Monthly mean maximum Tmax & 0.01 & 0.00 & 0.02 & 0.01 & 0.01 \\
\hline $\begin{array}{llll} & \text {-Mann } & \text {-Kendall } & \text { stat. } \\
\text { (Tkrit_95\%) } & & & \end{array}$ & 0.10 & 0.03 & 0.26 & 0.11 & 0.23 \\
\hline -Trend / decade & 0.11 & 0.04 & 0.21 & 0.12 & 0.11 \\
\hline
\end{tabular}

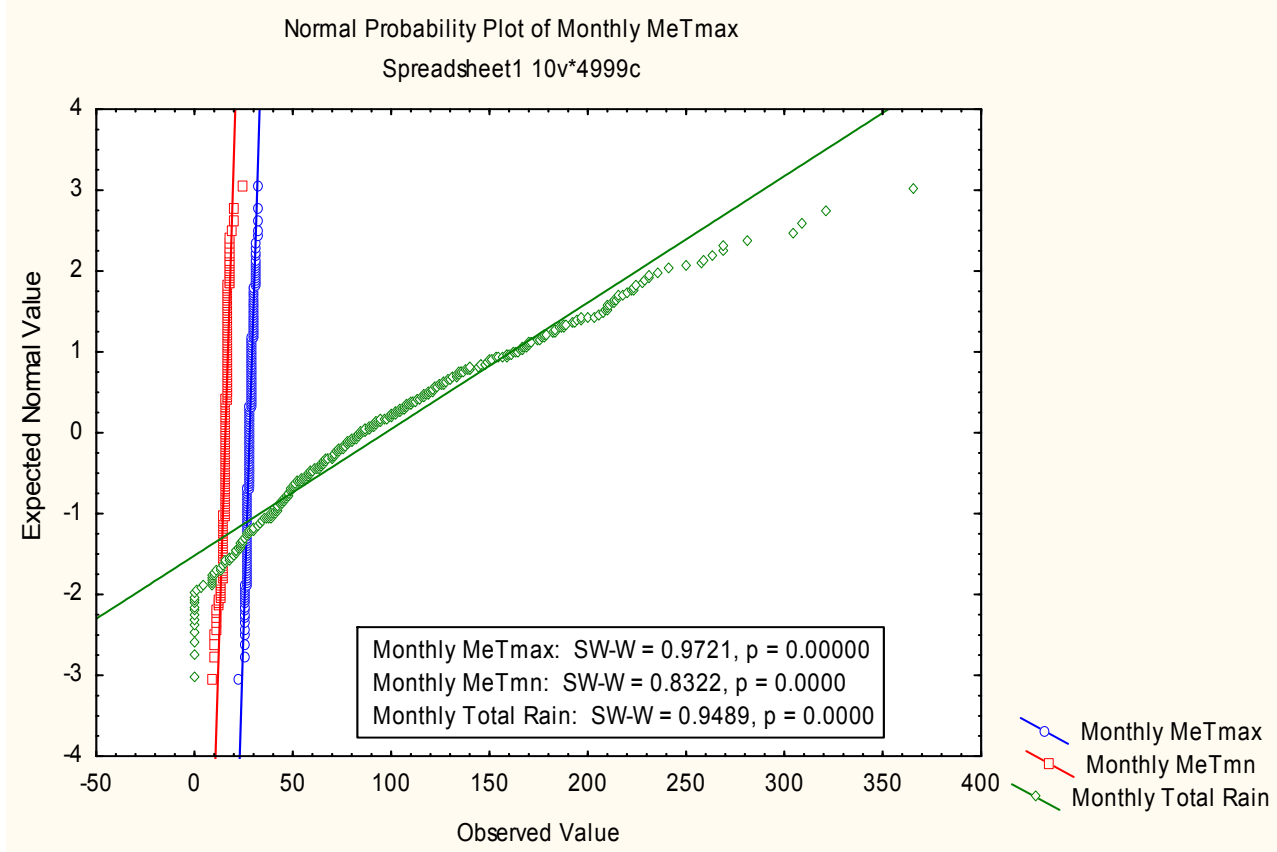

Figure 1. Normal probability plot for monthly mean maximum temperature, monthly mean minimum temperature and monthly total rainfall for Namulonge (1947 to 2009) 


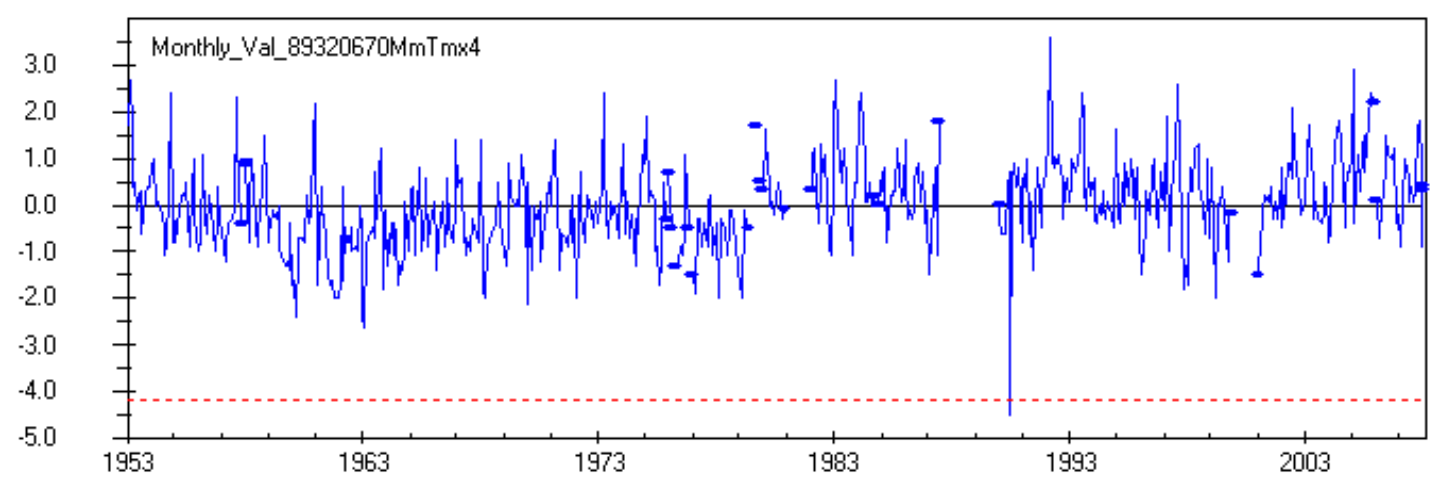

Figure 2(a). Monthly mean maximum temperature anomalies in ${ }^{0} \mathrm{C}$ for Namulonge.

Values are expressed as a departure from the long- term mean (1953 to 2008)

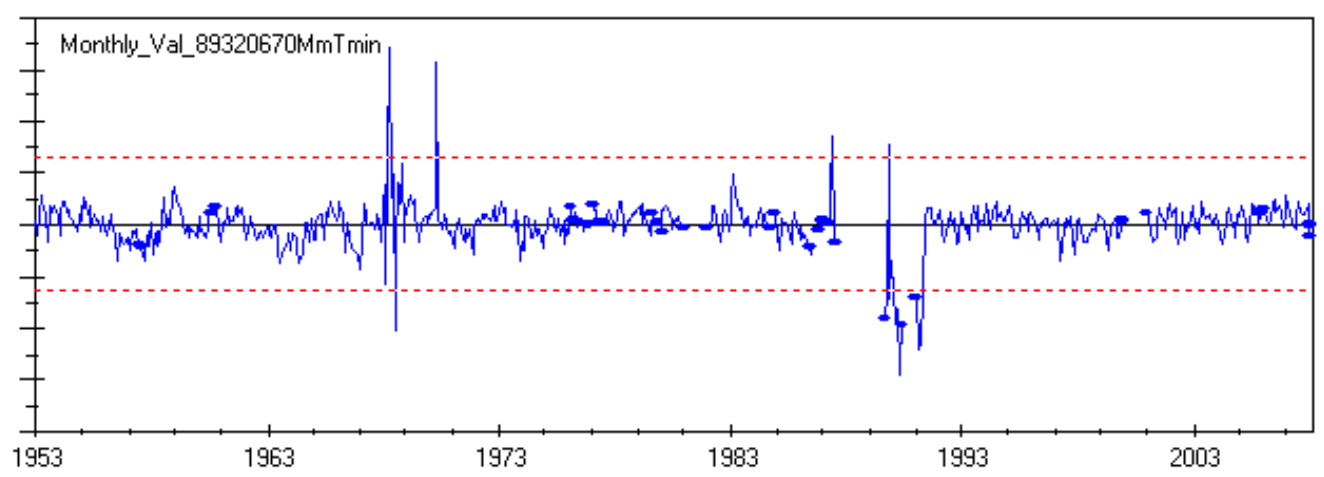

Figure 2(b). Monthly mean minimum temperature anomalies in ${ }^{0} \mathrm{C}$ for Namulonge.

Values are expressed as departures from long- term mean (1953 to 2008)

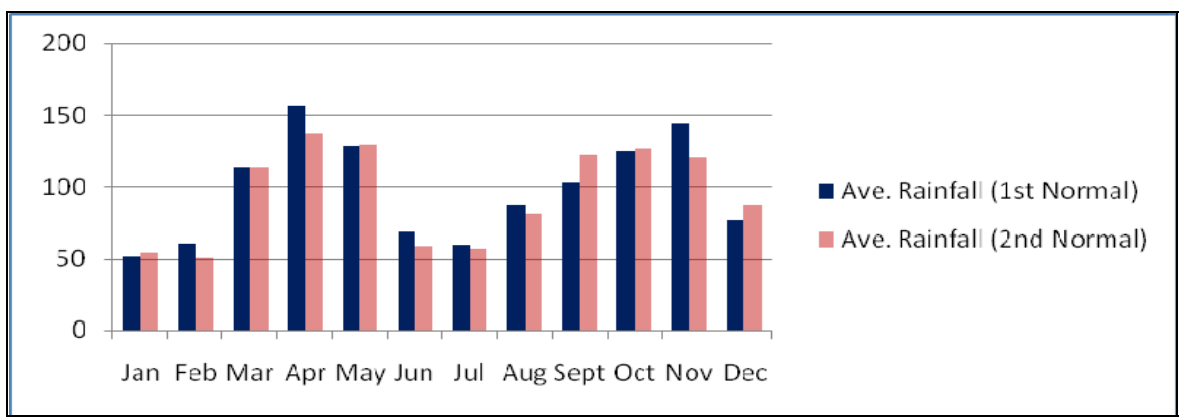

Figure 3. Two normals of rainfall in mm verses months (1947 to 2009)
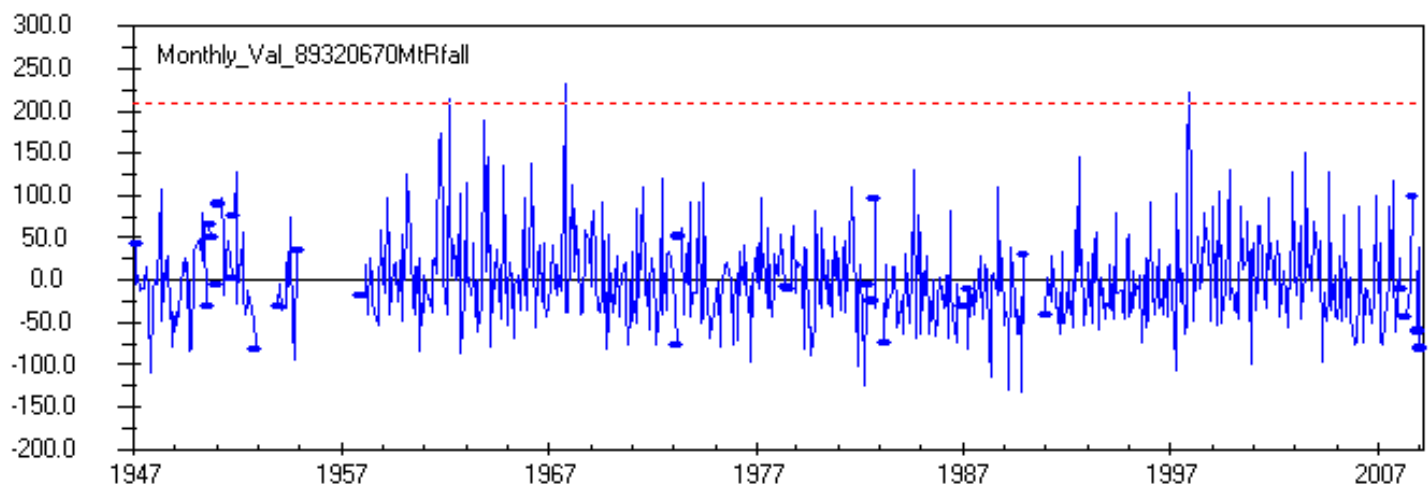

Figure 4. Monthly mean total rainfall anomalies in $\mathrm{mm}$ for Namulonge. Values are expressed as a departure from long-term mean (1947 to 2009) 


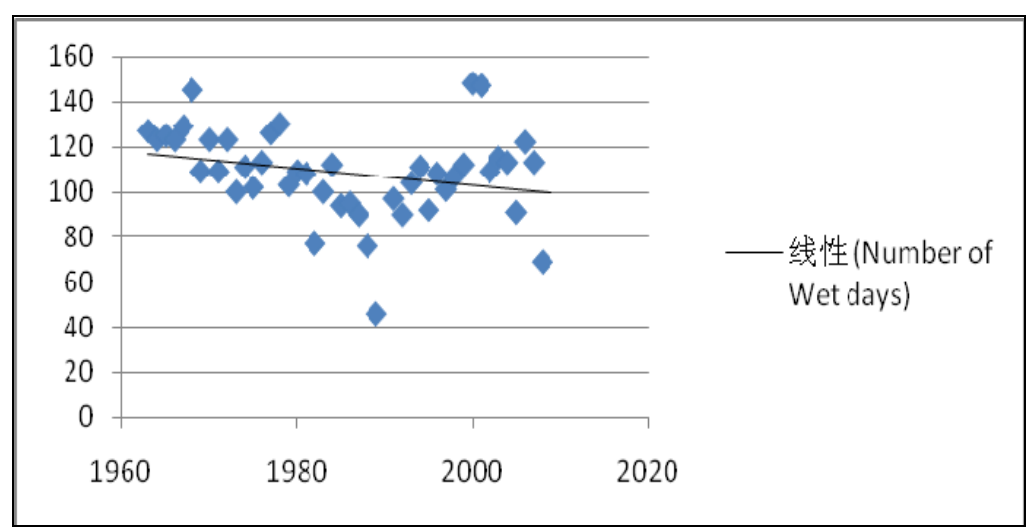

Figure 5. Distribution of number of wet days during the period 1960 to 2009

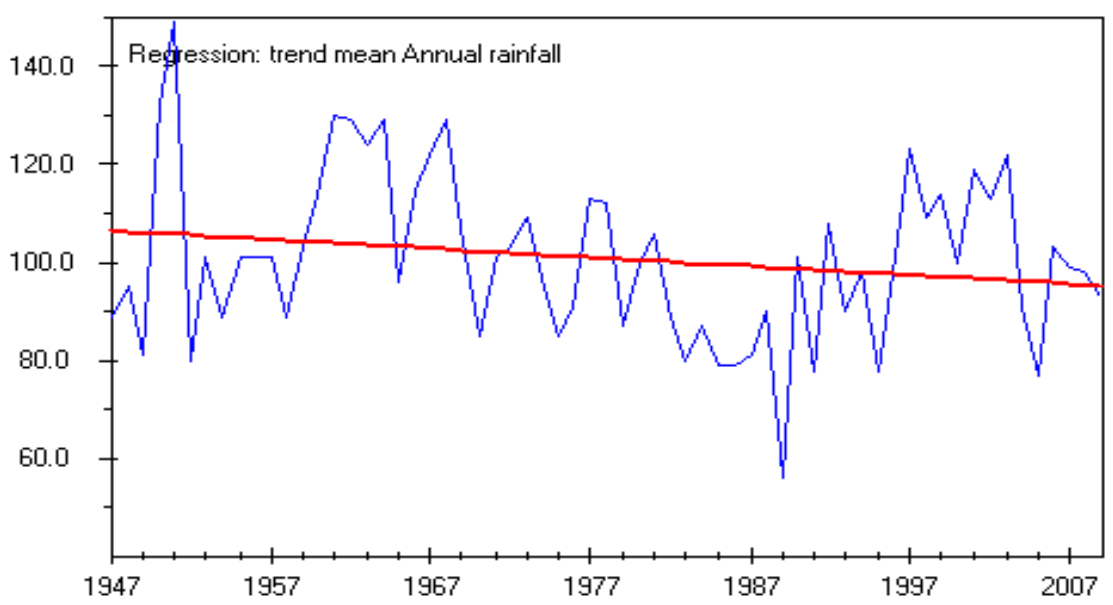

Figure 6. Time series of mean annual rainfall in mm for Namulonge for the period 1947 to 2009

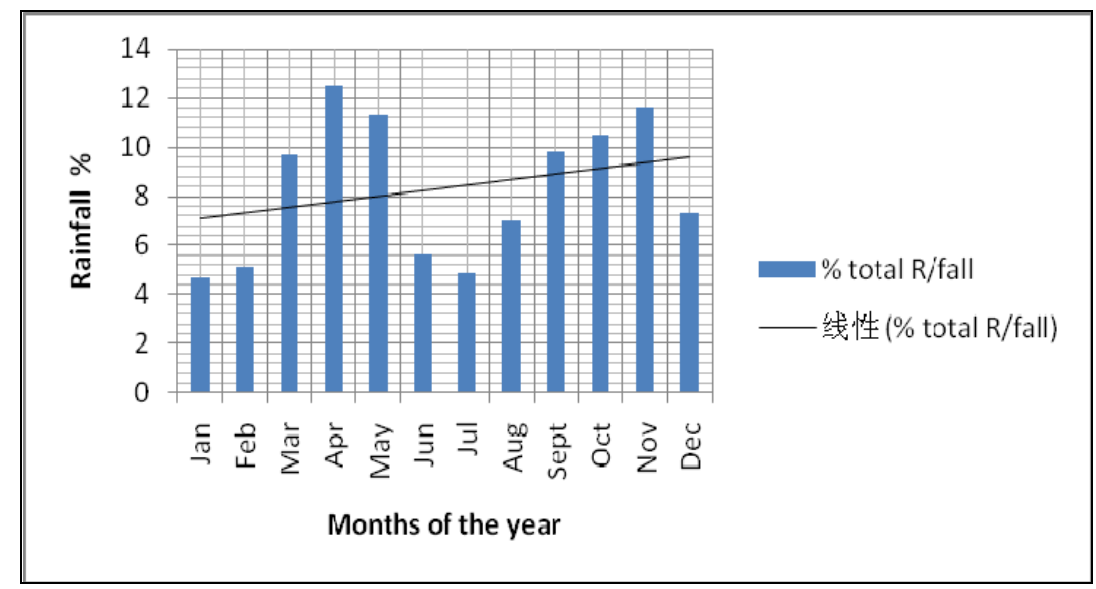

Figure 7. Monthly rainfall as a percentage of total rainfall, (1947 to 2009) 